の特集一高分子の科学亡技術のあゆみ

今加ら約 20 年前, 筆者らはまったく食品とは無縁の

化学会社の研究所に勤務しながら，コピー食品の一

つである人工イクラを作ってみようと思い立った，その 理由は，食品の性質を分析的に把握し，それを他の原料 を使って再現するという作業は，高分子工業における人 造織維や人造皮革の製造などといかにも類似しているこ とに気付いたからである.

むっとも食品の場合は，高分子といってあ天然の可食 性高分子しか原料として使用できないとか，味や臭いの 問題はあるが，それが高分子の成形加工である限り，コ ピー食品はわれわれ高分子科学にたずさわる者が取り組 むのに好適な課題であると思われた。

さてイクラという食品は，その美しい外観が命であ る. そして天然イクラの観察から，その美観を再現する には図 1 に示したような構造のカプセルを作る必要が あることがわかった，すなわち，透明皮膜に包まれた淡 橙色水性ゾル（基材）之濃橙色油滴（目玉）の間の色と 屈折率のコントラストによってイクラの美観が生まれて いる，また，食感をよくするためには，皮膜は強勒で薄 いものであることが好ましい.

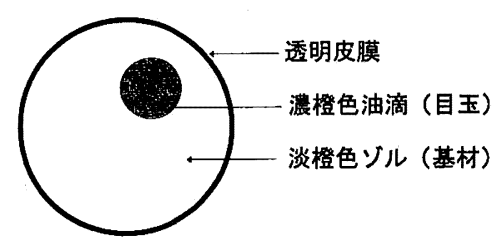

図 1 イクラの模型的構造

まず研究は使用する材料選びから始まった，天然イク ラの皮膜はコラーゲンからなっているが，コラーゲンは 取り扱いに不便であり，工業的に人工イクラを製造する ための原料としては適当ではないと判断された，コラー ゲンの代替えとしていろいろな物質を検討したが，結論 として海草から抽出される高分子であるアルギン酸ナト リウムが好適であるということになった。

アルギン酸ナトリウムの水溶液は安定に取り扱うこと ができ, しかむ塩化カルシウムの水溶液との接触で瞬間 的にゲル化するからである．さらに好都合なことに，こ のように生成したアルギン酸カルシウムの皮膜の触感は コラーゲンの皮膜とかなり類似している.

次に, 図 1 に示したカプセルの基材を構成する水性ゾ ルの原料である.これには, やはり海草からの抽出物で あるがカルシウムで架橋し難いカラギーナン，あるいは 陸上植物から得られるローカストビーンガムやアラビア ガムなどの可食性高分子水溶液が使用される，また，図 1 において目玉と称する油滴の存在は，このカプセルを 天然のイクラと同じょうに見せるために不可欠のあので

\section{海草から作った 人エイクラ}

\author{
Artificial Salmon Roe \\ Made from Seaweeds
}

\section{紙尾康作 \\ KAMIO Kosaku \\ 日本カーバイド工業(株)}

あるが, 油滴の原料としては上質のサラダ油が適当であ る.

基材である水性ゾルは淡橙色に着色され，油滴は濃橙 色に着色されるが，この目的には，それぞれ水溶性およ び油溶性の天然赤色系色素を用いるのが好ましい．

以上のような原料の組合せによって天然イクラ之識別 し難いカプセルを試作することができたが，その量産装 置の開発は容易ではなかった、イクラは魚卵の中では大 粒ではあるが，1 個の重さは $0.2 \mathrm{~g}$ 程度のものである. 1 時間当たり $100 \mathrm{~kg}$ の工イクラを製造するためには 50 万粒／時間の造粒が必要になる。いろいろな装置を 試作しては失敗を重ねた末に，三重ノズルを作り，中心 にサラダ油, 中間層に基材ゾル, 外層にアルギン酸ナト リウム水溶液を同時に滴下するむのを考案した。

滴下された液は空中で表面張力の作用によって図 1 に示したような構造の液滴となり, 塩化カルシウム水溶 液中に落下する．液滴の外層は直ちにゲル化されて皮膜 を構成し, 図 1 のようなカプセルが得られる.この装置 の考案によってようやく量産の目途が得られた.

研究の後を振り返ってみると, 人工的にイクラと識別 し難いまでのコピー食品を作るという風変わりなテーマ ではあったが，それも高分子科学の基礎をただ忠実に実 行することで完成できたという感が強い. 今一つの感想 は，これまで世の中に存在しなかった新しいものを工業 生産するには，それに適合する製造装置の考案がいかに 重要な役割を担っているかということであった。

（日本カーバイド工業(株)・顧問, 工博. 専門=高分子 化学) 